\title{
Augalų energinès apykaitos balansas ir jo vertinimas
}

\author{
Povilas Algimantas Sirvydas \\ Aleksandro Stulginskio \\ universitetas, Studentu g. 11, \\ LT-53361 Akademija, Kauno r. \\ El.paštas: algimantas.sirvydas@asu.lt
}

\section{Vidmantas Kučinskas}

$U A B$ „ARVI“ ir ko,

V. Kudirkos g. 24

LT-68305 Marijampole

El.paštas:vidmantas@arvi.lt

\begin{abstract}
Augalų energinès apykaitos procesai tiesiogiai susieti su pasaulinio masto problemomis (maisto ir bioenergijos), kurias galima apibūdinti kaip Saulès energijos akumuliaciją ir jos koncentraciją biologine forma. Augalo energijų balanso nagrinèjimas ir vertinimas išryškina veiksnius, turinčius ịtakos augalo energinės apykaitos vyksmui. Pagrindiniu augalo energinès apykaitos rodikliu yra transpiracijos skaičius $S_{k^{\prime}}$, kuris išreiškiamas energijos, sunaudotos transpiracijai ir konvekciniams šilumos mainams su aplinka, santykiu. Staigiausi transpiracijos ir šilumos mainų su aplinka pokyčiai stebimi prie mažų transpiracijos skaičiaus $S_{k}(1-3)$ reikšmių. Augalų atiduota aplinkai šiluminè energija, vandens garo ir aplinkos temperatūros pavidalo šiluma dalyvauja sudarant lokalų mikroklimatą.
\end{abstract}

Raktažodžiai: augalo energijų balansas, biomasès energetika, transpiracijos energetika, augalo energinė apykaita

\section{IVADAS}

Energiniai procesai, vykstantys augale, tiesiogiai susieti su pasaulinio masto problemomis (maisto ir energijos), kurias galima apibūdinti kaip Saulès energijos akumuliaciją ir jos koncentraciją biologineje formoje. Tvermès dèsnis teigia - energija nesukuriama ir nesunaikinama, galima tik energijos formos transformacija. Nepriklausomai nuo augalo sukurtos biomasės panaudojimo tikslo (maistui ar biomasès energetikai), naudojama biomasè negali išskirti daugiau energijos negu augale akumuliuota saulès energija. Vadinasi, atsinaujinančios energijos panaudojimo plètra tiesiogiai priklauso nuo asimiliacijos proceso, nuo žaliojo Žemès rūbo biologinių galimybių tenkinti biomasès poreikius.

Šiuolaikiniu technologiju amžiuje žmogus bet kurios formos energiją sèkmingai gali panaudoti energetinèse technologijose tik tada, kai ji yra koncentruota (anglis, nafta, biomasė ir kt.). Saulès energijos, kaip atsinaujinančio energijos šaltinio, kaupimas biologine forma (aliejai, organinis kuras ir kt.) vyksta asimiliacijos procese. Asimiliacijos procesas tiesiogiai priklauso nuo biologinių procesų augale, kuriuos veikia daugelis veiksnių, pvz., augalo energinè ir medžiaginė apykaita.

Démesys krypsta $\mathfrak{i}$ augalo lapo asimiliacinio aparato teorinį pajègumą, kuris idealiu atveju didesnis nei $20 \%$ $[1,2]$. Faktinis saulès energijos panaudojimas organinès medžiagos kūrimui yra apie $2 \%$. Minimumo (limituojančio veiksnio) dèsnis, galiojantis augalų pasaulyje, nurodo, kad gyvybinius procesus (tarp jų ir derlių) esant kitoms vienodoms sąlygoms lemia veiksnys, esantis minimume. Vertinant aplinkos veiksnius būtina turèti augalo energinès apykaitos su aplinka teorinị vertinimą.

Termodinaminiu požiūriu augalas yra prastas saulès spindulinès energijos transformatorius. Organiniu junginių sintezei panaudoja tik 1-2\% visos sugertos spindulinès energijos $[3,4]$. Augalu derlius D yra dalis augalo sukurtos biomasès (produktyvumo), kuri turi praktinę vertę. Ji 
ivvertinama derliaus indeksu DI. Kuo šis indeksas yra didesnis, tuo didesné sukurtos augale biomasès dalis, panaudojama praktiniams tikslams. Aukštą derliaus indeksą turi žemès ūkio augalai (DI $=0,81)$. Mediena sumedejusiuose augaluose sudaro apie $60 \%(\mathrm{DI}=0,6)$ sukurtos biomasės. Visos planetos metinis augalų produktyvumas siekia tik $0,336 \mathrm{~kg} / \mathrm{m}^{2}$, žemès ūkio augalu $-0,6-0,7 \mathrm{~kg} / \mathrm{m}^{2}$. Produktyviausi visžaliai miškai $-1,3-2,2 \mathrm{~kg} / \mathrm{m}^{2}$ biomasès [5]. Biomasės poreikio didejimas Žemëje siejamas ne tik su maisto poreikių augimu, bet ir su biomasės panaudojimo energetikai plètra. Šiuo metu Žemeje vienam gyventojui tenka apie 0,115 ha ariamos žemès ir tiek pat miško ploto. Europos Sajungos valstybėse didèja susirūpinimas dèl pusiausvyros tarp medienos pasiūlos ir paklausos atsižvelgiant ị planuojamą biomasės panaudojimą energetikoje. Šiuo metu miško metinis prieaugis yra apie 900 , kirtimai $-500 \mathrm{mln} . \mathrm{m}^{3}$. Gerai, kad dabartinis bendras medienos derlius išlieka gerokai mažesnis už metini prieaugi [6,7].

Kita vertus, augalas yra unikali, pigi bet kartu ir labai sudètinga laboratorija. Augalas sugeba panaudoti nekoncentruotą saulès spindulinę energiją ir sukurti didžiausią Žemès turtą - organinę medžiagą, sunaudoti didžiają dalị šiuolaikinio technologinio žmogaus i aplinką išmetamu teršalų, tiekti deguoni aplinkai sukuriant gyvybei Žemėje sąlygas. Žemès rutulio augalija per metus asimiliuoja apie $640 \mathrm{mlrd}$.t anglies dioksido ir išskiria apie $500 \mathrm{mlrd}$. t laisvo deguonies, tuo mažindama aplinkos taršą [1,2], transpiruoja (išgarina) apie $65200 \mathrm{~km}^{3}$ vandens [8].

Saulès energija, augale virtusi šiluma, naudojama ir augalo mineralinès (peleninès) mitybos elementams iš ekosferos pasisavinti. Augalų biomasèje peleniniai elementai (K, Na, Ca, Mg, Fe, S ir kt.) sudaro vidutiniškai 5 \% sausosios masès. Šiluma taip pat naudojama asimiliacijos proceso metabolitų $\left(\mathrm{O}_{2}, \mathrm{H}_{2} \mathrm{O}\right.$ garų $)$ šalinimui. Sausos medžiagos $1 \mathrm{~kg}$ sukurti, skirtingi augalai išgarina nevienodą vandens kiekị. Miškuose taupiausiai organinès medžiagos kūrimui drègmę naudoja eglè - apie $200 \mathrm{~kg} / \mathrm{kg}$, išlaidžiausiai - beržas - apie $350 \mathrm{~kg} / \mathrm{kg}$ [9].

Natūraliomis aplinkos sąlygomis augalų energinė apykaita ir ją lydintys energiniai procesai tarp augalo ir jo apsupties vyksta nenutrūkstamai. Augalas su jo apsupties aplinka sudaro vientisą nedalomą sistemą, kurioje vyksta augalų energinè apykaita. Saulès spindulinè energija, augaluose transformuota ị šilumą, sudaro $96-98 \%$ bendro energijos kiekio, dalyvaujančio augalų energinèje apykaitoje. Augalų atiduota aplinkai menkavertè, žemo potencialo šilumos energija, vandens garu ir aplinkos temperatūros pavidalo šiluma, toliau dalyvauja vandens ir oro apytakos cikluose, formuoja Žemejje klimatines sąlygas $[2,10]$. Energinès apykaitos tarp augalo $\leftrightarrow$ aplinkos prognozavimo ir vertinimo pagrindiniai veiksniai yra šviesa (spinduline energija), temperatūra (šiluma) ir drègmè (vanduo). Šiuos tris aplinkos veiksnius, sąlygojančius augalo produktyvu- mo, minimalios egzistencijos ir žūties sąlygas (kaip termoenerginius procesus), galima nagrinèti panaudojant termodinamikos dèsnius (augalo energijų balanso metodu).

\section{AUGALO ENERGIJU BALANSAS}

Augalo terminès problemos nuo seno domina tyrejus [1113]. Augalo lapo lokali temperatūra yra augalo lape vykstančių biologinių procesų ir energinès apykaitos su aplinka rezultatas, kurị lemia daugelis veiksnių [14]. Energijos balanso metodas teigia, kad bet kuriam augalo gyvavimo momentui galioja lygybè tarp gautos, sukauptos, sunaudotos biologiniams procesams ir atiduotos aplinkai (šilumos ir vandens garo pavidalu) energijos [2,15-17].

Energijų balanso metodika, pritaikyta augalui ar jo daliai, padeda suprasti pagrindinius veiksnius, turinčius itakos augalo energinès apykaitos proceso vyksmui, nurodo būdus ir veiksnius, kuriais galima pakreipti vykstantị procesą norima linkme. Pvz., siekiant reguliuoti augalo audinių temperatūrą, augale vykstančių procesų intensyvumą, siekti maksimalaus poveikio terminèse žemès ūkio technologijose $[18,19]$. Išanalizavus augalo energijų balanso narius, paaiškejja augale vykstančių fiziologinių procesų kryptingo valdymo galimybès. Remiantis augalo energijų balansu, galima ịvertinti visus energijų apykaitos pokyčius natūralioje ir žmogaus sukurtoje aplinkoje, nagrinèti augalo $\leftrightarrow$ aplinkos energinius procesus, pvz., transpiracijos proceso, konvekcinių šilumos mainų, lapų vytimo, rasos iškritimo, radiacinės šalnos, augalo energinių mainų šiltnamio sąlygomis, energinius procesus piktžolių terminès kontrolès metu, augalo terminio žuvimo, iš dalies augalo terminio pažeidimo, apibūdinti optimalius terminès aplinkos veiksnius, augalo energinės apykaitos procesams.

Augalo lapo energinès apykaitos kitimą, kaip dinaminio energijų balanso išraišką, galime nagrinèti sprendžiant energinio balanso lygti. Temperatūros kitimas augalo lape pasireiškia lapo audinių termoakumuliacijos procesu, kuris savo ruožtu iššaukia konvekcinių šilumos mainų su aplinka intensyvumo pokyčius. Saulètu paros metu ore esančios drègmės kondensacija lapo paviršiuje negalima, todèl energinio balanso narys, ịvertinantis drègmès kondensaciją, lygus nuliui ir nevertinamas. Šilumos srautas su augalo sulčiu tekèjimu, kaip labai mažas dydis, taip pat atmestinas. İvertinę paminètas sąlygas, galime rašyti augalo energijų balanso lygtị:

$$
\Sigma Q= \pm Q_{1} \pm Q_{2}-Q_{3} \pm Q_{4} \pm Q_{5} \pm Q_{6}=0 .
$$

Augalo energijų balanso lygti (1) galime išreikšti procentais arba dalimis:

$$
\Sigma q= \pm q_{1} \pm q_{2}-q_{3} \pm q_{4} \pm q_{5} \pm q_{6}=1 \text { arba } 100 \% \text {; }
$$


čia: $Q_{1}, q_{1}$ - bendras efektyvus augalo, jo aplinkos ir saulès energijos srautas. J/s arba šilumos srauto tankis $\mathrm{J} /\left(\mathrm{s} \cdot \mathrm{m}^{2}\right)$;

$Q_{2}, q_{2}$ - atitinkamai - šilumos srautas, atiduodamas arba gaunamas iš aplinkos konvekciniais šilumos mainais. $\mathrm{J} / \mathrm{s}$ arba konvekcinis šilumos srauto tankis $\mathrm{J} /\left(\mathrm{s} \cdot \mathrm{m}^{2}\right)$;

$Q_{3}, q_{3}$ - atitinkamai - šilumos srautas, sunaudotas transpiracijai ir atiduodamas aplinkai vandens garo pavidalu. J/s arba srauto tankis $\mathrm{J} /\left(\mathrm{s} \cdot \mathrm{m}^{2}\right)$;

$Q_{4}, q_{4}$ - atitinkamai - šilumos srautas augalo audiniais per laidị, kurị sukelia temperatūrų skirtumas augalo audiniuose $\mathrm{J} / \mathrm{s}$, arba srauto tankis $\mathrm{J} /\left(\mathrm{s} \cdot \mathrm{m}^{2}\right)$;

$Q_{5}, q_{5}$ - atitinkamai - šilumos srautas, energijos pavidalo fotocheminems reakcijoms ir kitiems augale vykstantiems egzo- ir endoterminiams procesams $\mathrm{J} / \mathrm{s}$, arba srauto tankis $\mathrm{J} /\left(\mathrm{s} \cdot \mathrm{m}^{2}\right)$;

$Q_{6}, q_{6}$ - atitinkamai - šilumos srautas, dalyvaujantis augalo audinių termoakumuliacijos procese $\mathrm{J} / \mathrm{s}$, arba srauto tankis $\mathrm{J} /\left(\mathrm{s} \cdot \mathrm{m}^{2}\right)$.

Analizuodami augalo energijų balanso atskirų narių ittaką, ịvertinę energinès apykaitos sąlygas aplink augalą, kai kuriais atvejais galime supaprastinti augalo balanso lygtis (1) ir (2). Galime parinkti augalo energinès apykaitos laikotarpị, kai nẻra šilumos mainų augalo audinių laidžiu $\left(Q_{4}=0\right)$, šiluma egzo- ir endoterminiams procesams $\left(Q_{5}=0\right)$, termoakumuliacijai $\left(Q_{6}=0\right)$. Tada augalo lapo (ar kitos dalies) energijų balanso lygtis (1) ir (2), îvertinančias pagrindinius energinés apykaitos balanso narius (absorbuojamą saulès energiją $Q_{1}$, konvekcinius šilumos mainus su aplinka $Q_{2}$ ir transpiraciją $Q_{3}$ ), bet kuriuo nagrinejjamu atveju galime išreikšti taip:

$$
a b q_{s p}=q_{1}= \pm q_{2}+q_{3} ;
$$

arba

$$
a b Q_{s p}=q_{1}= \pm q_{2}+q_{3}
$$

čia: $a$ - koeficientas, kuriuo įvertinama absorbuotos saulès energijos dalis, augale virstanti šiluma $\%$ arba dalimis $(a=0,96-0,98)$;

$b$ - augalo absorbuojama saulès integralinès spinduliuotès dalis $\%$ arba dalimis $(b=0,34-0,37)$ [2];

$Q_{s p}, q_{s p}$ - atitinkamai saulès integralinès spinduliuotes srautas $\mathrm{J} / \mathrm{s}$ arba srauto tankis $\mathrm{J} /\left(\mathrm{s} \cdot \mathrm{m}^{2}\right)$.

Augalo lapo energinès apykaitos procese dalyvaujanti saulès energija $Q_{1}$ ir šilumos energija, dalyvaujanti konvekciniuose šilumos mainuose su augalo aplinka $Q_{2}$, priklausomai nuo saulès energijos ir konvekcinių šilumos srautų krypties, gali būti teigiamos arba neigiamos. Nagrinèdami augalo energijų balansus laikomès tokių sutartinių ženklų: tiekiant augalui šilumą iš aplinkos (kai šilumos srautas iš aplinkos nukreiptas ị augalą) energijų balanso narys yra teigiamas, ir atvirkščiai - kai augalas šilumą atiduoda aplinkai (kai šilumos srautas nukreiptas iš augalo ị aplinką), energijų balanso narys yra neigiamas. Tai priklauso nuo augalo ir jo aplinkos energinés apykaitos. Transpiracijos procese energijos srautas vandens garo pavidalu $Q_{3}$ visais atvejais nukreiptas iš augalo ị aplinką, todèl jis visuomet yra neigiamas. Priklausomai nuo augalo energinès apykaitos procese dalyvaujančių energiju $Q_{1}$, $Q_{2}, Q_{3}$ srautų dydžio ir krypties, galimi 6 augalo ir jo aplinkos energijų balanso atvejai.

\section{AUGALŲ ENERGINĖS APYKAITOS BALANSO VERTINIMAS}

Augalų energinès apykaitos procesų ịvairovė yra labai didelè. Augalijoje energijų apykaitos procesų, vykstančiu tarp augalo ir jo apsupties, ịvairove pasireiškia kaip augalo fiziologinis atsakas ị energinès apykaitos pokyčius augalo apsuptyje. Augalo energijų apykaitos procesų nagrinëjimas išryškino, kad augalo fiziologinis-reguliacinis mechanizmas (augale vykstantys fiziologiniai procesai) reaguoja i termodinaminių parametrų kitimą apsuptyje ir pasireiškia pokyčiais augalo energinëje apykaitoje. Augalo biologinis atsakas i duoto momento energinès apykaitos atveji augale pasireiškia energijų srautų paskirstymu tarp pagrindinių energiju balanso narių: spindulinès energijos, transpiracijos, konvekciniu šilumos mainų, atskirais atvejais (rūko aplinkoje atvejis) ijungiant bioenerginius procesus, iššaukiančius temperatūrų gradientą tarp augalo organo ir aplinkos.

Augalo lapo masè maža, todèl maži jo sukauptos šilumos kiekiai sukelia ryškius augalo audinių temperatūros pokyčius. Augalas, kovodamas su didejjančia audinių temperatūra, sukauptą saulès energiją, virtusią šiluma, tuoj pat atiduoda augalo aplinkai transpiracijos ir konvekcinių šilumos mainų būdu. Saulètu paros metu augalo lapo temperatūra yra nuolat kintamos energijų balanso būsenos. Kuo lapas plonesnis, kuo mažesnès jo termoakumuliacinès galimybès, tuo lapo temperatūros kaita didesnè.

Augalo transpiracija - sudètingas fiziologinis termofizikinis procesas. Jis susideda iš dviejų atskirų procesų. Pirmojo proceso metu augalo sultys kapiliarais juda iki garinančio paviršiaus (fiziologinis procesas), o antruoju - vanduo išgarinamas ị aplinką (termofizikinis procesas). Transpiracijos procesas kartu yra ir augalo, ir aplinkos energinès $Q_{3}$ apykaitos (energijos ir drègmès mainu su aplinka termodinaminis) procesas, kuriam galioja termofizikos desniai. Transpiracijos procesas nevyks, jei augalas negaus energijos.

Augalas per ilgą vystymosi periodą prisitaikè prie augavietès fizikinès aplinkos (taip pat ir energinès) veiksnių, panaudodamas tam tikrus fiziologinius procesus. Todèl transpiracijos proceso energetikos pokyčiai neatskiriami nuo adekvataus augalo fiziologinių procesų atsako. 
Augalo fiziologinẻ būsena adekvačiai ịvertina esamą energinès apykaitos atveji su aplinka ir optimaliai paskirsto energijų srautus tarp skirtingų energijos rūšių (saulès energijos, vandens garavimo, konvekcinių šilumos mainų ir kai kuriais atvejais - biologinės energijos).

Laikoma, kad pagrindinis drègmès pašalinimo iš lapo būdas (80-98 \%) yra žiotelinè transpiracija. Lapą dengia vaško sluoksnis ir kiti epidermio dariniai. Užsivèrus žiotelèms, lapas gali garinti vandenị pro kutikuloje esančius kanalèlius. Žiotelių varstymasis priklauso nuo saulès spinduliuotès intensyvumo, aplinkos temperatūros ir drègnio, augalo aprūpinimo drègme ir kitų energinių, fiziologinių veiksnių.

Natūraliomis aplinkos sąlygomis apatinejje lapo pusèje vyksta transpiracija ir šilumos mainai su aplinka, o viršutinejje - konvekciniai šilumos mainai. Kutikulinė transpiracija būna labai maža arba visiškai nevyksta. Esant tokioms sąlygoms augalo lapo energijos balanso lygtis (3) ir (4) galima sudaryti taip:

$$
a b Q_{s p}=a Q_{1}=Q_{2}^{\text {virs }}+Q_{2}^{a p}+Q_{3}
$$

arba

$$
a b q_{s p}=a q_{1}=q_{2}^{v i r \check{r}}+q_{2}^{a p}+q_{3}
$$

čia: $Q_{2}^{\text {virš }}, Q_{2}^{a p}$ - šilumos srautas, atiduodamas aplinkai konvekcinių mainų būdu, atitinkamai viršutinès arba apatinès lapo pusès $\mathrm{J} / \mathrm{s}$, arba šilumos srauto tankis $q_{2}^{\text {viř }}, q_{2}^{a p}$ $\mathrm{J} /\left(\mathrm{s} \cdot \mathrm{m}^{2}\right)$.

Nagrinėjamuoju atveju abi lapo pusès (apatine ir viršutinè) praktiškai turi vienodas aplinkos sąlygas vykdyti konvekcinius šilumos mainus (saulès spindulius lapas sugeria visu storiu). Tokiu atveju galima teigti, kad tarp lapo viršutinès ir apatinès pusių didesnio temperatūrų skirtumo nebūna. Remdamiesi šiuo teiginiu galime sudaryti tokias lygtis:

$$
\begin{aligned}
& Q_{2}^{\text {viřs }}=Q_{2}^{a p} ; \\
& Q_{2}^{\text {virš }}+Q_{2}^{a p}=2 Q_{2 \text { min }} ;
\end{aligned}
$$

čia: $Q_{2 \min }-$ minimalus šilumos srautas $Q_{2}$, sunaudojamas transpiracijos proceso metu aplinkos orui šildyti, kai augalas išgarina $1 \mathrm{~kg}$ drègmès $\mathrm{J} / \mathrm{s}$.

Šilumos srautų pasiskirstymą augalo lape nusako transpiracijos skaičius $S_{k}$. Jis rodo: kokia dalis gautos saulès energijos sunaudojama transpiracijai ir kokia aplinkos orui šildyti kiekvienu augalo energinès apykaitos atveju. Transpiracijos skaičius - tai bedimensinis dydis, išreiškiamas lygtimi:

$$
S_{k}=\frac{Q_{3}}{Q_{2 \min }} .
$$

Nustatyta, kad $S_{k}$ priklauso nuo augalo lapo temperatūros ir aplinkos oro parametrų (aplinkos temperatūros $t_{0}$ ir santykinio oro drégnio $\varphi_{0}$ ) [10]. Transpiracijos skaičiaus $S_{k}$ funkcinė priklausomybè nuo matavimo priemonèmis išmatuojamų parametrų bendru atveju išreiškiama lygtimi:

$$
S_{k}=f\left(t_{0}, t_{1}, \varphi_{0}\right)
$$

čia: $\varphi_{0}$ - santykinis aplinkos oro drègnis \%;

$t_{1}$ - augalo lapo temperatūra ${ }^{\circ} \mathrm{C}$;

$t_{0}$ - aplinkos temperatūros ${ }^{\circ} \mathrm{C}$.

Naudodamiesi (9) lygtimi transpiracijos skaičiui $S_{k}$ apskaičiuoti, (5) lygti galime perrašyti taip:

$$
a Q_{1}=\left(\frac{2}{S_{k}}+1\right) Q_{3} \text {. }
$$

Irašę išraišką $Q_{3}=w r$, gauname lygtị, transpiracijos intensyvumui apskaičiuoti:

čia: $r$ - vandens garavimo šiluma $\mathrm{kJ} / \mathrm{kg}(r=2465 \mathrm{~kJ} / \mathrm{kg}$ esant $\left.15^{\circ} \mathrm{C}\right)$;

$w$ - transpiracijos intensyvumas $\mathrm{kg} /\left(\mathrm{m}^{2} \cdot \mathrm{s}\right)$;

$$
w=\frac{a q_{1}}{\left(\frac{2}{S_{k}}+1\right) r}=\frac{a b q_{s p}}{\left(\frac{2}{S_{k}}+1\right) r} .
$$

Transpiracijos intensyvumui nustatyti (12) lygti naudojame tais atvejais, kai vandeni garina viena lapo pusé, kartu dalyvaudama konvekciniuose šilumos mainuose; kita lapo pusė dalyvauja tik konvekciniuose šilumos mainuose su aplinka. Šiam atvejui 1 pav. pateikiame transpiracijos $w$ intensyvumo priklausomybę nuo transpiracijos skaičiaus $S_{k}$ esant tam tikrai saulès integralinei spinduliuotei $q_{s p}$.

Transpiracijos intensyvumas ir konvekciniai šilumos mainai su aplinka abiejose lapo pusèse būna vienodi termiškai naikinant piktžoles, tada aplinkos temperatūra būna $100-1000{ }^{\circ} \mathrm{C}$. Apie transpiracijos intensyvumą šiuo atveju sprendžiame iš 2 pav. pateiktų duomenų arba lygties:

$$
w=\frac{a q_{1}}{\left(\frac{1}{S_{k}}+1\right) r}=\frac{a b q_{s p}}{\left(\frac{1}{S_{k}}+1\right) r} .
$$

Lygčių (12) ir (13), taip pat 1 ir 2 pav. analizè rodo, kad transpiracijos intensyvumas priklauso nuo dviejų kintamųjų, t. y. lapo absorbuotos integralinès saulès spinduliuotès $Q_{s p}\left(q_{s p}\right)$ ir transpiracijos skaičiaus, kuriuo išreiškiamas energijos srautu pasiskirstymo santykis $S_{k}=\frac{Q_{3}}{Q_{2 \min }}$. Esant mažoms transpiracijos skaičiaus $S_{k}$ reikšmėms (nuo 0 iki 3) nedidelis šio skaičiaus kitimas sukelia nemažus transpiracijos intensyvumo pokyčius.

Kintant skaičiaus $S_{k}$ reikšmėms nuo 3 iki 10 ir esant mažiems saulès spinduliuotès srauto pokyčiams mažai keičiasi 


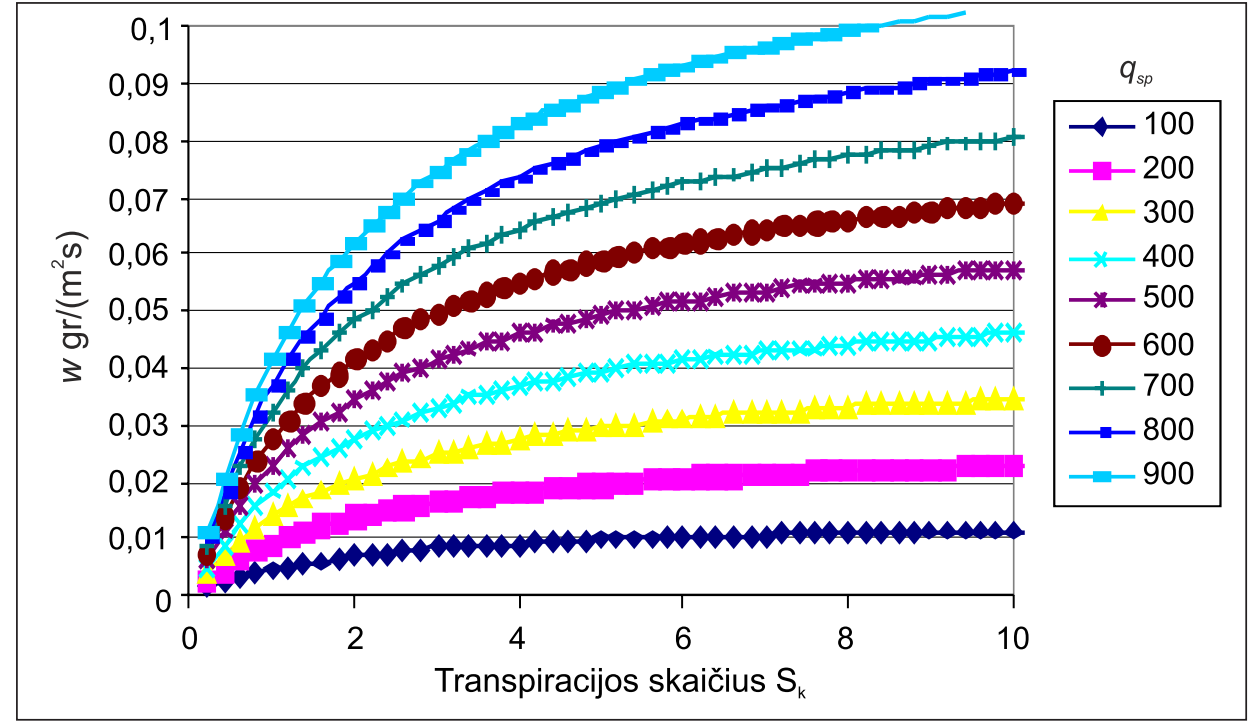

1 pav. Transpiracijos intensyvumo $w$ priklausomybe nuo transpiracijos skaičiaus $S_{k}$ esant atitinkamam saulès integralinès spinduliuotès srautui $q_{s p}$. Vandenį garina viena lapo pusẻ

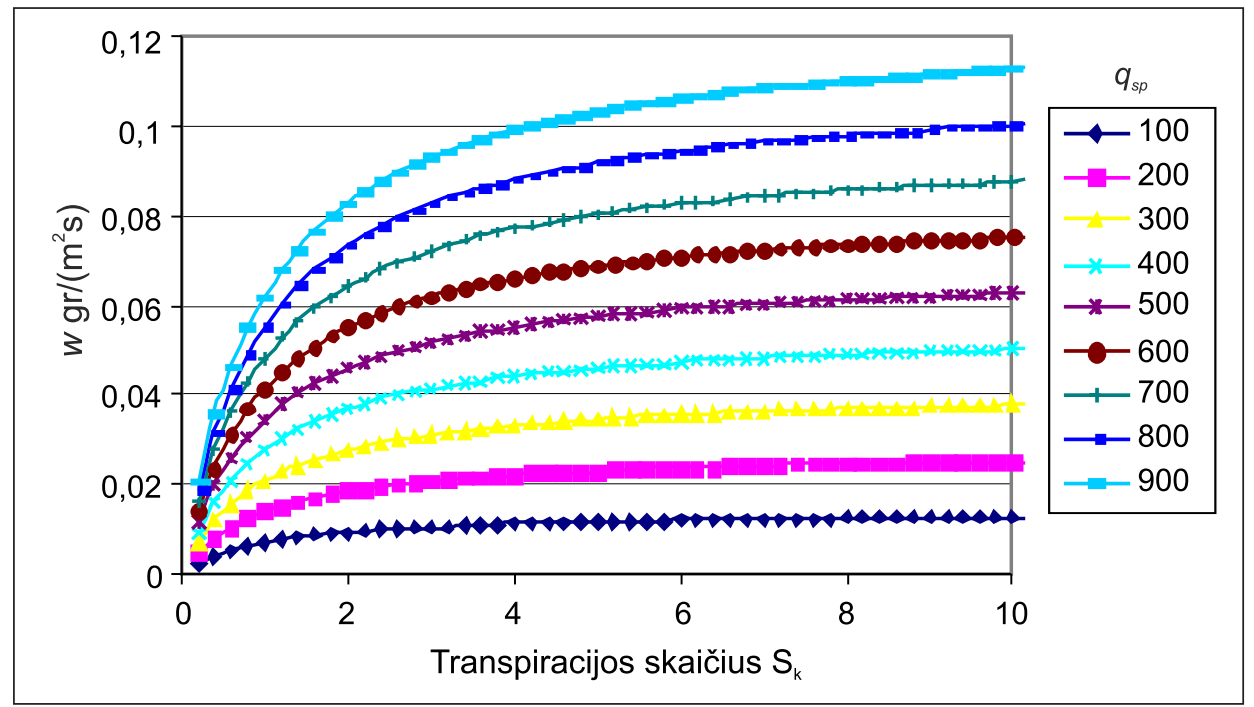

2 pav. Transpiracijos intensyvumo $w$ priklausomybè nuo transpiracijos skaičiaus $S_{k}$ esant tam tikram saulès integralinės spinduliuotès srautui $q_{s p}$. Vandenį garina abi lapo pusès

transpiracijos intensyvumas. Remdamiesi I. A. Šulgino duomenimis, apskaičiavę transpiracijos skaičiaus skaitinę vertę, matome, kad jis realiai kinta nuo 0,1 iki 10 [20].

Kaip matome iš balanso lygčių (5) ir (6), augalo energijų mainai su aplinka (transpiracija ir konvekciniai šilumos mainai) yra glaudžiai susiję. Naudodamiesi (9) ir (5) lygčių išraiškomis, gauname (14) lygtị, nustatyti augalo konvekciniams šilumos mainams su aplinka:

$$
Q_{2}=\frac{Q_{1}}{S_{k}+1}=\frac{a b Q_{s p}}{S_{k}+1} .
$$

Lygti (14) arba 3 pav. naudojame tais atvejais, kai abi lapo pusès vienodai garina vandenị ir yra vienodi konvekciniai šilumos mainai su aplinka. Jei transpiracija vyks- ta tik vienoje augalo lapo pusèje, o konvekciniai šilumos mainai - abiejose, tai šilumą, atiduotą aplinkai konvekcijos būdu, apskaičiuojame pagal lygtị:

$$
Q_{2}=\frac{Q_{1}}{S_{k}+2}=\frac{a b Q_{s p}}{S_{k}+2} .
$$

3 ir 4 pav. pateikiame augalo lapo konvekcinių šilumos mainų su aplinka priklausomybę nuo transpiracijos skaičiaus $S_{k}$ ir saulès integralinès spinduliuotes srauto $q_{s p}$.

Pagal 1, 2, 3 ir 4 pav. pateiktus duomenis galima teigti, kad staigiausi transpiracijos ir šilumos mainų su aplinka pokyčiai pastebimi esant mažoms transpiracijos skaičiaus $S_{k}$ reikšmėms. Aptariant šilumos mainų su aplinka duomenis (3, 4 pav.) matyti, kad mažejant transpiracijos skaičiui 


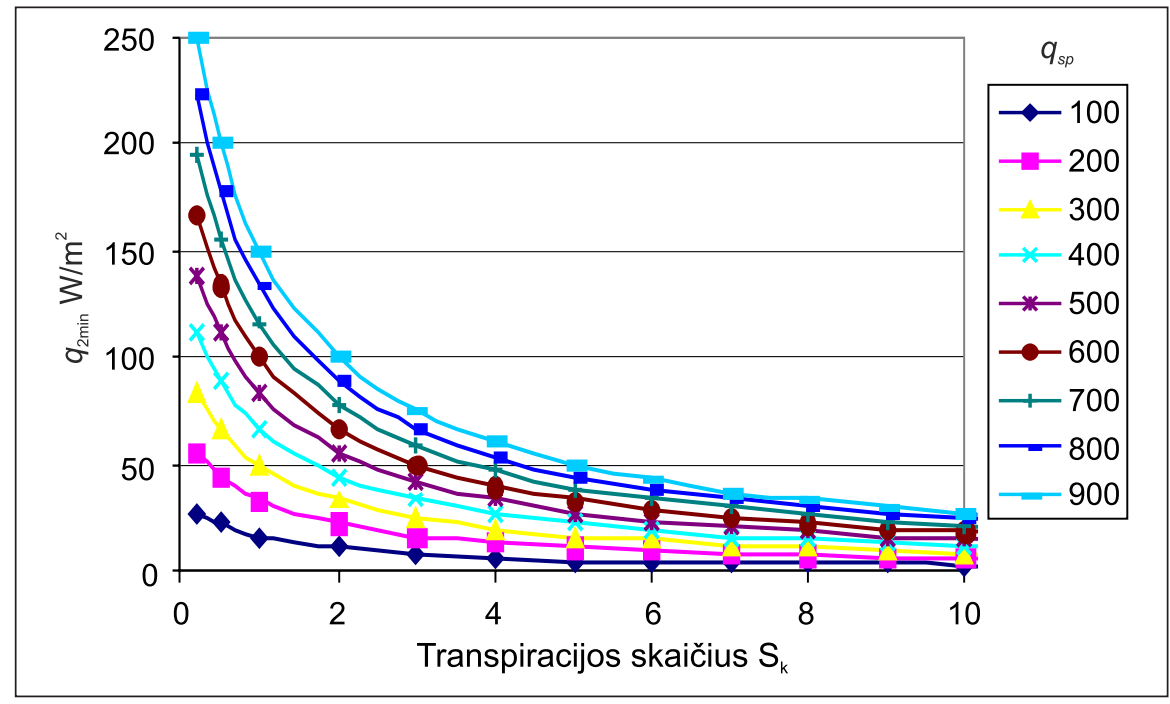

3 pav. Konvekcinių šilumos mainų su aplinka $q_{2 \text { min }}$ priklausomybè nuo transpiracijos skaičiaus $S_{k}$ esant tam tikram saulès integralinės spinduliuotės srautui $q_{s p}$. Vandeni garina abi lapo pusès

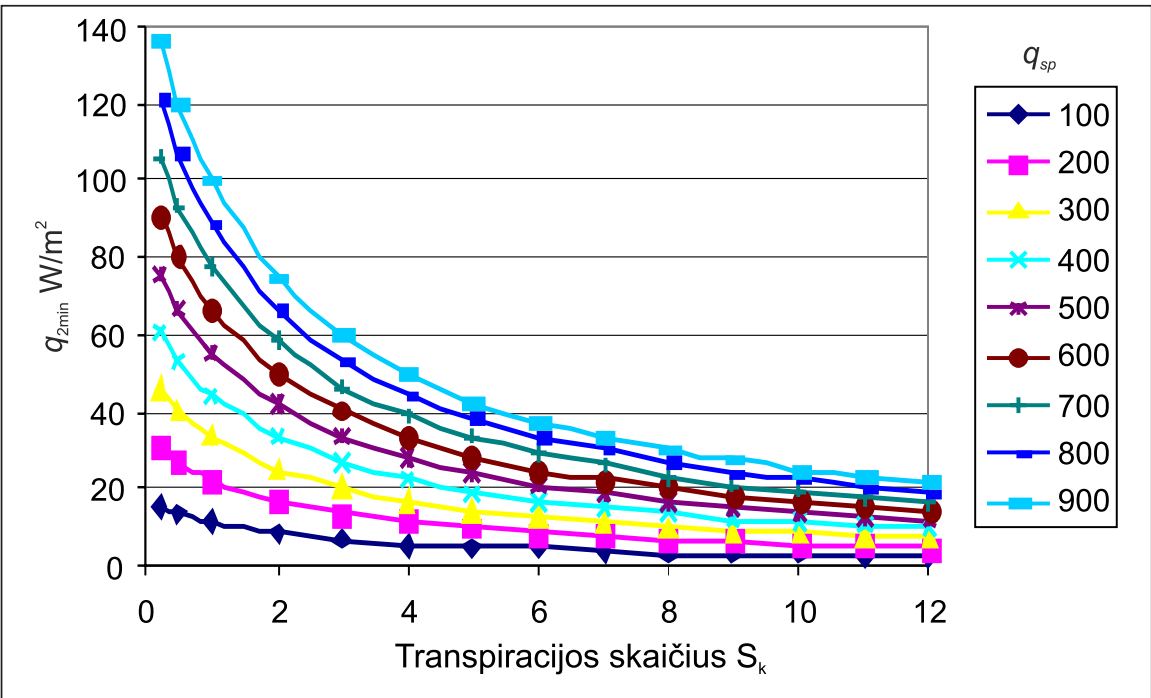

4 pav. Konvekcinių šilumos mainų su aplinka $q_{2 \min }$ priklausomybė nuo transpiracijos skaičiaus $S_{k}$ esant tam tikram saulès integralinės spinduliuotès srautui $q_{s p}$. Vandeni garina viena lapo pusè

$S_{k}$ konvekciniai šilumos mainai su aplinka kinta staigiau. Lygindami transpiracijos intensyvumo (1,2 pav.) ir konvekcinių šilumos mainų ( 3,4 pav.) duomenis, akivaizdžiai matome tiesiogini šių procesų ryši: vienam didèjant kitas atitinkamai mažèja.

Transpiracijos procesas minimalios energinès apykaitos sąlygomis esant neigiamam efektyviam šiluminiam spinduliavimui vyksta antroje dienos puseje - mažèjant augalo ir oro temperatūrai. Tai laikotarpis, kai transpiruojančio augalo temperatūra $t_{1}$ yra $\left(t_{s l}<t_{1}<t_{0}\right)$ aukštesnè už šlapio termometro temperatūrą ir žemesnè už aplinkos temperatūrą. Kai augalo energinè apykaita minimali, esant neigiamai $\left(-Q_{1}\right)$ spinduliuotei energinio balanso lygtis būtų tokia:

$$
Q_{3}=Q_{2}^{v i r \check{s}}+Q_{2}^{a p}-Q_{1}
$$

Nagrinëjamuoju atveju, kaip ir esant teigiamai efektyviajai spinduliuotei, abi augalo lapo pusès turi vienodas konvekcinių šilumos mainų sąlygas. Tarp lapo viršutinès ir apatinès pusių didesnio temperatūrų skirtumo nẻra, todèl konvekciniams šilumos mainams įvertinti taikytinos (7) ir (8) lygtys. Augalo lapas gaunamą šilumą iš aplinkos sunaudoja transpiracijai ir neigiamam efektyviajam spinduliavimui $i$ aplinką. Tokiu atveju balanso lygti (16) galima sudaryti taip:

$$
2 Q_{2}=Q_{1}+Q_{3}
$$

arba 


$$
Q_{3}=w r=2 Q_{2}-Q_{1} \text {. }
$$

Remdamiesi transpiracijos skaičiaus $S_{k}=\frac{Q_{3}}{Q_{2}}$ išraiška, (18) lygti galime perrašyti taip:

$$
w=\frac{Q_{1}}{\left(\frac{2}{S_{k}}-1\right) r} .
$$

Transpiracijai nustatyti (19) lygti naudojame tais atvejais, kai vandeni garina viena lapo pusè.

Tais atvejais, kai transpiracijos procese ir konvekciniuose šilumos mainuose vienodai dalyvauja abi lapo pusės, transpiracijos intensyvumas skaičiuojamas pagal lygtị:

$$
w=\frac{Q_{1}}{\left(\frac{1}{S_{k}}-1\right) r} .
$$

Sauletu paros metu augale intensyviausiai vyksta ne tik energinè apykaita, bet ir cikliški biologiniai procesai. Šiuo paros metu vykstančiu energijos procesų termodinaminé analizė yra ypač aktuali, nes nagrinèjami veiksniai daro ịtaką svarbiausiam Žemëje procesui - asimiliacijai.

Pateikti duomenys leidžia teigti, kad pagrindinis augalo energinès apykaitos rodiklis yra transpiracijos skaičius $S_{k}$, kuriuo nusakomas energijos, sunaudotos transpiracijai ir konvekciniams šilumos mainams su aplinka, santykị ir išreiškiamas (9) lygtimis. Kaip matome iš (10) lygties, transpiracijos skaičius $S_{k}$ priklauso nuo augalo aplinkos oro ir lapo paviršiaus oro fizinių parametrų. Transpiracijos skaičius $S_{k}$ priklauso nuo aplinkos oro temperatūros $t_{0}$, jos santykinio drégnio $\varphi_{0}$ ir vandeni garinančio lapo paviršiaus temperatūros $t_{1}$.

\section{IŠVADOS}

1. Augalo energijų balanso nagrinejjimas ir vertinimas padeda išryškinti veiksnius, turinčius ịtakos augalo energinès apykaitos vyksmui.

2. Pagrindiniu augalo energinès apykaitos rodikliu yra transpiracijos skaičius $S_{k}$, kuris išreiškiamas energijos, sunaudotos transpiracijai ir konvekciniams šilumos mainams su aplinka, santykiu.

3. Staigiausi transpiracijos ir šilumos mainų su aplinka pokyčiai pastebimi esant mažoms transpiracijos skaičiaus $S_{k}$ (1-3) reikšmèms.

4. Augalų atiduota aplinkai šiluminè energija, vandens garų ir aplinkos temperatūros pavidalo šiluma, toliau dalyvauja lokalaus mikroklimato sudaryme.

Gauta 20130104 Priimta 20130305

\section{Literatūra}

1. Šlapakauskas V. Augalu ekofiziologija. Kaunas: Lututè, 2006. 413 p.

2. Ilkun G. M. Energetičnij balans roslin. Kiev, 1967. $234 \mathrm{~s}$.

3. Fitter A., Hay R. Environmental Physiology of Plants. Academic Press, 2002. 367 p.

4. Kleschnin A. F. Die Pflanze und das Licht. Berlin: Akademie Verlag, 1960. 620 p.

5. Šlapakauskas V., Duchovskis P. Augalu produktyvumas. IDP Solutions, 2008. 254 p.

6. Dzenajavičienè E., Pedišius N., Škèma R. Darni bioenergetika. Lietuvos energetikos institutas. Kaunas, 2011. 136 p.

7. Europos aplinka-Būklè ir perspektyvos $2010 \mathrm{~m}$. Apibendrinimas. EEA, Copenhagen, 2011. 222 p.

8. Brazauskienè D. M. Agroekologija ir chemija. Kaunas, 2004. 207 p.

9. Ruseckas J. Miško ir drègmès sq̨veika. Kaunas: Lututè, 2002. 200 p.

10. Sirvydas A., Kerpauskas P., Kučinskas V. Augalu energine apykaita. Kaunas, Akademija, 2011. 224 p.

11. Brown H. T., Escombe F. Researches on some of the processes of green leaves. Proceedings of the Royal Society. 1905. Series B, 76. No. 507. P. 92-118.

12. Stern K. Pflanzenthermodynamik. Berlin: Springer, 1933. $412 \mathrm{~s}$.

13. Radčenko S. I. Temperaturnije gradienti sredi i rastenija. Moskva: Nauka, 1966. 386 s.

14. Sirvydas A., Kučinskas V., Kerpauskas P., Nadzeikienė J. Theoretical modeling of temperature pulsations in plant leaf which are caused by leaf swing with respect to the sun. Journal of Environmental Engineering and Landscape Management. 2011. Vol. 19(3). P. 251-259.

15. Herve C., Lluis C., Xavier R., Thierry A. Unraveling the effects of plant hydraulics on stomatal closure during water stress in walnut. Plant Physiology. 2002. Vol. 128. P. 282-290.

16. Sirvydas A., Kučinskas V., Kerpauskas P., Nadzeikienè J., Kusta A. Solar radiation energy pulsations in a plant leaf. Journal of Environmental Engineering and Landscape Management. 2010. Vol. 18(3). P. 188-195.

17. Sirvydas A., Kerpauskas P. Energinių procesų agrofito aplinkoje aspektai. Energetika. 2006. Nr. 4. P. 9-15.

18. Sirvydas A., Kerpauskas P. Terminis piktžoliu naikinimas. Kaunas, Akademija: Aleksandro Stulginskio universitetas, $2012.328 \mathrm{p}$.

19. Petruševičius V., Raila A. Augalininkystès produktų džiovinimas storame nejudančiame sluoksnyje. Akademija, 2009. $262 \mathrm{p}$.

20. Shulgin I. A. Solnechnaya radiaciya i fotomorfogenez zelionovo rasteniya. Avtoreferat dis. dr. biol. nauk. Leningrad, 1970. $40 \mathrm{~s}$. 
Povilas Algimantas Sirvydas, Vidmantas Kučinskas

\section{BALANCE OF ENERGY TRANSFER IN PLANTS AND ITS ASSESSMENT}

Summary

The processes of plant energy transfer are directly related with worldwide scope issues (food and bioenergy), which may be called as solar energy accumulation and its concentration in biological forms. The analysis and assessment of plant energy balances highlight factors which have impact on the process of plant energy transfer. Transpiration No $S_{k}$ is the main indicator of plant energy metabolism, which is reflected in the ratio of energy, consumed for transpiration and convection heat exchange with the environment. The most abrupt changes of transpiration and heat exchange with the environment are observed at small values (1-3) of the transpiration number $S_{k}$. Thermal energy released by plants to the environment in the form of water vapour and environment temperature heat participates in the formation of local microclimate.

Key words: energy balance of plants, biomass energy, transpiration energy, energy transfer in plants
Повилас Альгимантас Сирвидас, Видмантас Кучинскас

\section{ЭНЕРГЕТИЧЕСКИЙ ОБМЕН РАСТЕНИЙ, ЕГО БАЛАНС И ОЦЕНКА}

Резюме

Процессы энергетического обмена непосредственно связаны с проблемами мирового масштаба - биоэнергетики, ресурсы питания, которые могут быть обобщены в виде аккумуляций солнечной энергии и ее концентрации в биологической форме. Исследованиями баланса энергии растений выяснены причины влияния на энергетический обмен растений. Основным показателем энергетического обмена является число транспирации $S_{k}$, который определяется соотношением энергии использованной для транспирации и конвективного теплообмена с окружающей средой. Самые резкие изменения транспирации и теплообмена с окружающей средой наблюдается при малых числах транспирации $\left(S_{k}=1-3\right)$. Растениям окружающей среде отдана тепловая энергия в виде водяного пара и тепло окружающей среды участвует в формировании локального микроклимата.

Ключевые слова: баланс энергии растения, энергетика биомассы, энергетика транспирации, энергетический обмен растения 